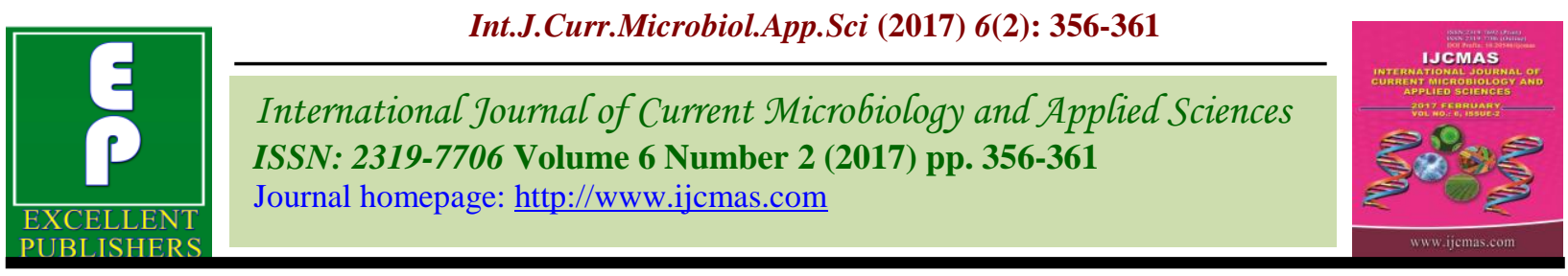

Original Research Article

http://dx.doi.org/10.20546/ijcmas.2017.602.039

\title{
Detection of Promising Cross Combinations on the Basis of Standard Heterosis and Specific Combining Ability in Kharif Sorghum
}

\author{
R.B. Ghorade*, Vikas Mangal, Dipali P. Thakare, V.V. Kalpande and K.S. Pagire
}

All India Coordinated Sorghum Improvement Project, Akola Centre, Sorghum Research Unit, Dr. Panjabrao Deshmukh Krishi Vidyapeeth, Akola-444104 (M.S.), India

*Corresponding author

\section{A B S T R A C T}

Keywords

Combining ability analysis, Standard heterosis, Line $\mathrm{x}$ tester, Sorghum.

Article Info

Accepted:

12 January 2017

Available Online:

10 February 2017
Six cytoplasmic male sterile lines (CGMS) and eleven testers were crossed in line $\mathrm{x}$ tester fashion and the resultant 66 hybrids were evaluated along with the checks (CSH 35) for grain yield per plant and fodder yield per plant through combining ability and heterosis analysis. The outcome of current investigation revealed that two dual purpose cross combinations was identified (ICS 751A x AKR 530 and ICS 733 A x AKR 529) having positive significant sca effects for grain yield and fodder yield per plant $(22.67 * *$ and $26.44 * *$ respectively) as well as positive significant standard heterosis for both grain yield per plant (44.27\% and $29.16 \%$ ) and fodder yield per plant $(29.16 \%)$. Likewise, four promising cross combinations (ICS 279 A x AKR 528, AKMS 89 A x AKR 492-1, AKMS 89 A x AKR 527, and ICS 733 A x AKR 530) recognized for grain yield per plant on the basis of significant positive sca effect $(13.87 * *, 9.20 * *, 8.93 * *, 7.37 * *$ respectively) and significant positive standard heterosis $(22.79 \%, 21.57 \%, 20.66 \%$, and $21.31 \%)$. With respect to fodder yield per plant, three promising crosses (AKMS 90A x AKR 527, ICS 279 A x AKR 526 and AKMS 89 A x AKR 523) had significant positive sca effect $(86.62 * *, 11.49 * *, 27.97 * *$ respectively) along with significant positive standard heterosis over the check CSH-35 (69.72\%, $23.02 \%$ and $14.25 \%$ respectively).

\section{Introduction}

Kharif sorghum is one of the important crop providing both grain for human consumption and fodder for the live stocks. The fodder is equally important in kharif sorghum because the fodder quality of kharif sorghum is good and fetches good market prize. So development of high grain as well as fodder yielding kharif sorghum hybrids is of prime importance.

The improvement in grain sorghum in the past was mainly based on selection in the locally adopted types and hybrid population.
However, during recent years, hybrid vigour and selection of parents based on specific combining ability (sca) have opened up a new approach in the crop improvement. Exploitation of heterosis on commercial scale and the systematic varietal improvement through hybridization are the main tools to increase the sorghum production. Stephens and Holland (1954) reported for the first time, the use of cytoplasmic genetic male sterility (CGMS) for developing hybrids of sorghum. The exploitation of heterosis by developing the hybrids is one of the quickest and simpler 
ways to improving productivity for grain as well as fodder yield with special reference to combining ability. This could be realized only when the male sterile and restorer lines having the seasonal adaptability and desired combining ability are identified and used in the development of kharif sorghum hybrids (Prabhakar, 2002).

Hence, this study was conducted to identify the promising cross combinations (dual, grain and fodder purpose) showing both positive significant sca effects along with positive significant standard heterosis for both grain yield as well as fodder yield.

\section{Materials and Methods}

The experimental material comprised of six newly developed cytoplasmic genic male sterile lines (CGMS) viz., AKMS 89 A, AKMS 90 A, ICS 279 A, AKMS 103-8 1A, ICS 751 A, ICS 733 and eleven testers viz., AKR 523, AKR 524, AKR 525, AKR 492, AKR 492-1, AKR 526, AKR 527, AKR 528, AKR 529, AKR 530, and AKR 531. These seventeen genotypes were crossed in line $\mathrm{X}$ tester fashion at Sorghum Research Unit, Dr. Panjabrao Deshmukh Krishi Vidyapeeth (PDKV), Akola, during rabi 2014-15. The produced 66 hybrids $\left(\mathrm{F}_{1}\right.$ 's) along seventeen parents and standard checks $(\mathrm{CSH}-35$ - for grain yield) were sown at Sorghum Research Unit, Dr. P.D.K.V., Akola, during kharif 2015-16 in randomized block design with three replications. The seed material was planted with inter and intra spacing of 45 and $15 \mathrm{~cm}$ respectively. Recommended package of agronomic as well as plant protection management practices and plant protection measures were adopted to raise a healthy crop. The observations were recorded on five randomly selected plants per plot per replication for grain yield per plant $(\mathrm{g})$ and fodder yield plant (g). The standard heterosis was estimated as per cent increase or decrease of the mean of $F_{1}$ over the value of the standard check CSH 35. The data on all the above characters were subjected to combining ability analysis by following Kempthorne (1957) method.

\section{Results and Discussion}

Analysis of variance revealed that the mean squares due to genotypes were highly significant for both grain yield per plant and fodder yield per plant (Table 1). This indicated the presence of substantial genetic variability for these characters. Further partitioning of genotypic variance into components viz., parents, females, males, hybrids and parents $v s$. hybrids revealed that the parents differed among themselves significantly for both the characters. Similarly, females also showed highly significant differences for grain yield per plant and fodder yield per plant. Further, the males, hybrids and parents $v s$. hybrids showed highly significant differences for both these characters. Analysis of variance for combining ability (Table 2 ) revealed that the crosses recorded significant variation for both grain and fodder yield per plant. The female $\mathrm{x}$ male interaction was also significant.

In the current investigation, among the 66 hybrids, the cross ICS 751 x AKR 30 recorded highest significant positive sca effect $(22.67 * *, 26.44 * *)$ and significant positive standard heterosis over the check CSH-35 $(44.27 \%, 29.16 \%)$ for grain yield per plant and fodder yield per plant respectively. Similarly, cross AKMS 90 A x AKR 527 obtained highest significant and positive sca effect for fodder yield per plant $(86.62 * *)$ along with greatest standard heterosis (69.72\%) as compare to other crosses. Even the same cross had significant positive sca effect for grain yield per pant $(14.58 * *)$ with positive standard heterosis (13.61\%). Further, another cross combination ICS $279 \mathrm{x}$ 
AKR 528 exhibited significant positive sca effect $(13.87 * *)$ and significant positive standard heterosis $(22.79 \%)$ but the performance of this cross for the fodder yield per plant was poor. With regards to hybrid ICS 733 A x AKR 529 had highly significant positive sca effect along with significant positive heterosis for grain yield per plant (11.84** and $26.31 \%$ resp.) and fodder yield per plant (21.18** and $19.15 \%$ resp.). The current data set indicated that ICS 751 A x AKR 530 and ICS 733 A x AKR 529 worked as dual purpose heterotic cross combinations. Prakash et al., (2010), Hariprasanna et al., (2012), Prabhakar et al., (2013) and Ghorade et al., (2014) also reported such promising crosses based on high sca effects and heterosis for grain yield as well as fodder yield in sorghum.

Moreover, another promising cross combination ICS 279 A x AKR 526 had significant sca effect for fodder yield per plant
$(11.49 * *)$ along with significant and positive standard heterosis (23.02 \%) while, significant positive sca effect for the grain yield per plant $\left(10.35^{* *}\right)$. In case of AKMS 89 A x AKR 492-1 significant positive sca effect was observed (9.20**) along with the significant positive heterosis $(21.57 \%)$ for grain yield per plant but showed negative sca effect for the fodder yield per plant $(-12.21 * *)$ with negative standard heterosis ($6.23)$. For grain yield per plant, another good heterotic combination was observed along with significant positive sca effect $(8.93 * *)$ and significant positive standard heterosis (20.66 \%) however, the fodder yield performance got limitation. High sca effects for grain yield along with other yield component characters suggested that improvement in grain yield by improving its associated component characters is to be done through systematic breeding efforts (Ghorade et al., 2013).

Table.1 Analysis of variance of parents and hybrids under Line x Tester analysis

\begin{tabular}{cccc}
\hline Source of Variation & $\begin{array}{c}\text { Degrees of } \\
\text { freedom }\end{array}$ & $\begin{array}{c}\text { Grain } \\
\text { Yield/ Plant (g) }\end{array}$ & $\begin{array}{c}\text { Fodder } \\
\text { Yield /Plant (g) }\end{array}$ \\
\hline Replications & 2 & 17.77 & 24.97 \\
Genotypes & 84 & $254^{* *}$ & $2589.48^{* *}$ \\
Parents & 16 & $72.03^{* *}$ & $984.94^{* *}$ \\
Females & 5 & $57.21^{*}$ & $954.36^{* *}$ \\
Males & 10 & $64.49^{* *}$ & $1091.57^{* *}$ \\
Females $v s$ Males & 1 & $221.5^{* *}$ & 71.63 \\
Hybrids & 65 & $245.4^{* *}$ & $2259.38^{* *}$ \\
Parents $v s$ Hybrids & 1 & $3718^{* *}$ & $49718.14^{* *}$ \\
Error & 168 & 24.72 & 44.14 \\
Note - * - Significant at 5\% level of significance & $* *$ & - Significant at 1 \% level of significance
\end{tabular}


Table.2 Analysis of variance for combining ability under Line $\mathrm{x}$ Tester analysis

\begin{tabular}{cccc}
\hline \multirow{2}{*}{ Source of variation } & Degrees of & Grain Yield/ Plant (g) & Fodder yield/ Plant (g) \\
\cline { 3 - 4 } freedom & 2 & 15.38 & 27.05 \\
\hline Replications & 65 & $245.45^{* *}$ & $2259.38^{* *}$ \\
Crosses & 5 & $585.11^{*}$ & 1062.19 \\
Lines & 10 & 245.71 & $4103.56^{*}$ \\
Testers & 50 & $211.43^{* *}$ & $2010.27^{* *}$ \\
Line x Testers & 130 & 28.82 & 43.24 \\
Error & Note $*$ - significant at 5\% level of significance & $* *$ & - significant at 1\% level of significance
\end{tabular}

Table.3 SCA effects and standard heterosis of promising hybrids for grain yield fodder yield per plant

\begin{tabular}{|c|c|c|c|c|c|c|}
\hline \multirow[b]{2}{*}{$\begin{array}{l}\text { Sr. } \\
\text { No. }\end{array}$} & \multirow[b]{2}{*}{ Crosses } & \multicolumn{2}{|c|}{ Grain yield per plant (g) } & \multicolumn{2}{|c|}{ Fodder yield per plant (g) } & \multirow[b]{2}{*}{$\begin{array}{c}\text { Significant SCA effects for } \\
\text { other characters }\end{array}$} \\
\hline & & $\begin{array}{c}\text { Standard } \\
\text { Heterosis (\%) } \\
\text { over } \\
\text { (CSH -35) } \\
\end{array}$ & $\begin{array}{c}\text { SCA effects } \\
\text { for grain } \\
\text { yield }\end{array}$ & $\begin{array}{c}\text { Standard } \\
\text { Heterosis (\%) } \\
\text { over } \\
\text { (CSH -35) } \\
\end{array}$ & $\begin{array}{c}\text { SCA effects } \\
\text { for fodder } \\
\text { yield }\end{array}$ & \\
\hline 1 & $\begin{array}{l}\text { ICS } 751 \text { A x } \\
\text { AKR } 530\end{array}$ & $44.27 * *$ & $22.67 * *$ & $29.16^{* *}$ & $26.44^{* *}$ & $2,3,4,5,7,8,9,10,12,14$ \\
\hline 2 & $\begin{array}{l}\text { AKMS } 90 \text { A } \\
\text { x AKR } 527\end{array}$ & 13.61 & $14.58^{* *}$ & $69.72 * *$ & $86.62^{* *}$ & $3,7,8,10,11,14$ \\
\hline 3 & $\begin{array}{l}\text { ICS } 279 \text { A x } \\
\text { AKR } 528\end{array}$ & $22.79 * *$ & $13.87 * *$ & -3.6 & 6.82 & $1,2,4,7,8,10,11$ \\
\hline 4 & $\begin{array}{l}\text { ICS } 733 \text { A x } \\
\text { AKR } 529\end{array}$ & $26.31 * *$ & $11.84^{* *}$ & $19.15^{* *}$ & $21.18^{* *}$ & $4,5,14$ \\
\hline 5 & $\begin{array}{l}\text { ICS } 279 \text { A x } \\
\text { AKR } 526\end{array}$ & 5.15 & $10.35^{* *}$ & $23.02 * *$ & $11.49^{* *}$ & $4,5,6,7,810,14$ \\
\hline 6 & $\begin{array}{l}\text { AKMS } 89 \text { A } \\
\text { x AKR 492-1 }\end{array}$ & $21.57 * *$ & $9.20 * *$ & -6.23 & $-12.21 * *$ & $1,2,5,7,8,10$ \\
\hline 7 & $\begin{array}{l}\text { AKMS } 89 \text { A } \\
\text { x AKR } 527\end{array}$ & $20.66^{*}$ & $8.93 * *$ & 1.17 & $-18.34 * *$ & $4,5,7,8,10$ \\
\hline 8 & $\begin{array}{l}\text { AKMS } 89 \text { A } \\
\text { x AKR } 523\end{array}$ & 13.76 & $8.65 * *$ & $14.25^{* *}$ & $27.97^{* *}$ & $3,4,57,8,10,12,14$ \\
\hline 9 & $\begin{array}{l}\text { ICS } 733 \text { A x } \\
\text { AKR } 530\end{array}$ & $21.31 * *$ & $7.37 * *$ & $18.66^{* *}$ & 2.31 & $3,4,5,7,8,10,11$ \\
\hline
\end{tabular}

Note- * - significant at 5\% level of significance $\quad * *$ - significant at $1 \%$ level of significance
1: Days to $50 \%$ flowering
2: Days to maturity
3: Plant height $(\mathrm{cm})$
4: Panicle Weight (g)
5: Panicle length $(\mathrm{cm})$
6: Panicle breadth $(\mathrm{cm})$
7: Number of primaries / panicle
8: Number of secondaries / panicle
9: Shoot fly Dead heart count 21(DAE)
10: Number of Grains/ Panicle
11: 1000 Seed Weight (g)
12: Grain Hardness
13: Grain Yield/ Plant (g)
14: Fodder Yield/ Plant (g) 
Table.4 Promising dual purpose (grain yield and fodder yield) cross combinations

\begin{tabular}{cccccc}
\hline \multirow{2}{*}{$\begin{array}{c}\text { Sr. } \\
\text { No. }\end{array}$} & Crosses & \multicolumn{2}{c}{ SCA effects } & \multicolumn{2}{c}{ Standard Heterosis (\%) } \\
\cline { 3 - 6 } & & $\begin{array}{c}\text { Grain } \\
\text { yield }\end{array}$ & $\begin{array}{c}\text { Fodder } \\
\text { yield }\end{array}$ & Grain yield & $\begin{array}{c}\text { Fodder } \\
\text { yield }\end{array}$ \\
\hline 1 & ICS 751A x AKR 530 & $22.67^{* *}$ & $26.44^{* *}$ & $44.27^{* *}$ & $29.16^{* *}$ \\
2 & ICS 733A x AKR 529 & $11.84^{* *}$ & $21.18^{* *}$ & $26.31^{* *}$ & $19.15^{* *}$ \\
\hline \multicolumn{2}{l}{ Note - $*$} & - significant at 5\% level of significance & $* *$ & - significant at 1\% level of significance
\end{tabular}

Table.5 Promising cross combinations for grain yield per plant in sorghum

\begin{tabular}{cccc}
\hline Sr. No. & Crosses & SCA effects & $\begin{array}{c}\text { Standard } \\
\text { Heterosis }(\%)\end{array}$ \\
\hline 1 & ICS 279 A x AKR 528 & $13.87^{* *}$ & $22.79^{* *}$ \\
2 & AKMS 89 A x AKR 492-1 & $9.20^{* *}$ & $21.57^{* *}$ \\
3 & AKMS 89 A x AKR 527 & $8.93^{* *}$ & $20.66^{* *}$ \\
4 & ICS 733 A x AKR 530 & $7.37^{* *}$ & $21.31^{* *}$ \\
\hline & Note - * & - significant at 5\% level of significance & $* *$ - significant at 1\% level of significance
\end{tabular}

Table.6 Promising cross combinations for fodder yield per plant in sorghum

\begin{tabular}{|c|c|c|c|}
\hline Sr. no. & Crosses & SCA effects & $\begin{array}{c}\text { Standard } \\
\text { Heterosis }(\%) \\
\end{array}$ \\
\hline 1 & AKMS 90 A x AKR 527 & $86.62 * *$ & $69.72 * *$ \\
\hline 2 & ICS 279 A x AKR 526 & $11.49 * *$ & $23.02 * *$ \\
\hline 3 & AKMS 89 A x AKR 523 & $27.97 * *$ & $14.25^{* *}$ \\
\hline
\end{tabular}

Likewise, AKMS 89 A $x$ AKR 523 had significant positive sca effect for fodder yield per plant $(27.97 * *)$ and significant positive heterosis $(14.25 \%)$ as well as recorded significant positive sca effect for grain yield per plant $\left(8.65^{* *}\right)$. The cross ICS $733 \mathrm{~A} x$ AKR 530 recorded significant positive standard heterosis over the check $\mathrm{CSH}-35$ $(21.31 \%)$ along with significant positive sca effect $\left(7.37^{* *}\right)$ for grain yield per plant. However, the significant positive heterosis exhibited $(18.66 \%)$ by the same cross for fodder yield per plant. Kalpande et al., (2016) reported seventeen promising cross combinations based on positive significant sca effects for grain yield per plant along with some of the component characters sorghum.

In conclusion, the outcome of current investigation revealed that total nine promising cross combinations were identified for yield and its associated traits for various purposes. Out of nine promising combinations, two dual purpose cross combinations has been identified (ICS 751A x AKR 530 and ICS 733 A x AKR 529) having positive significant sca effects for grain yield and fodder yield per plant $\left(22.67^{* *}\right.$ and $26.44 * *$ respectively) as well as positive significant standard heterosis for both grain yield per plant $(44.27 \%$ and $29.16 \%)$ and fodder yield per plant (29.16\%). However, four promising cross combinations (ICS 279 A x AKR 528, AKMS 89 A x AKR 492-1, AKMS 89 A x AKR 527, and ICS 733 A x AKR 530) recognized for grain yield per plant (Table 5). On the basis of significant positive sca effects $(13.87 * *, 9.20 * *, 8.93 * *, 7.37 * *$ respectively) and significant positive standard heterosis $(22.79 \%, 21.57 \%, 20.66 \%$, and $21.31 \%$ ). With respect to fodder yield per plant, three promising crosses (AKMS 90A x 
AKR 527, ICS 279 A x AKR 526 and AKMS 89 A x AKR 523) had significant positive sca effect $\quad\left(86.62 * *, \quad 11.49^{* *}, \quad 27.97 * *\right.$ respectively) along with significant positive standard heterosis over the check CSH-35 $(69.72 \%, 23.02 \%$ and $14.25 \%$ respectively) (Table 6). Hence, these combinations appeared to be best for further exploitation. Considering the current climate changing scenario, the dual purpose hybrids based on higher standard heterosis and specific combining effects for yield and its associated traits are need to be identified. Therefore, these crosses need to be evaluated on large scale multilocation and multiseason trials to find out the most stable cross combination for higher grain as well as fodder yield in kharif sorghum.

\section{References}

Ghorade, R.B., Kalpande, V.V., Bhongle, S.A. and Band, P.A. 2014. Combining ability analysis for drought tolerance and grain yield in rabi sorghum. Int. J. Agri. Sci., 10(1): 344-347.

Ghorade, R.B., Kalpande, V.V., Bhongle, S.A. and Band, P.A. 2013. Combining ability analysis for grain yield and yield components in post rainy season sorghum. Plant Archives, 13(2): 693696.

Hariprasanna, K., Rajendrakumar, P. and Patil, J.V. 2012. Parental selection for high heterosis in sorghum (Sorghum bicolor (L.) Moench) - Combining ability, heterosis and their relationship. Crop Res., 44(3): 400-408.

Kalpande, V.V., Vikas Mangal, R.B. Ghorade, S.S. Ghomashe, A.M. Dange, and S.A. Meshram. 2016. Promising tester for developing high grain and fodder yielding post rainy sorghum hybrids. Int. Conference On Plant Res. and Resource Mgt., Baramati (MS) India. Pp-56.

Kempthorne, O. 1957. An Introduction to genetic statistics. John Willey and Sons. Increased. New York, 468-470.

Prabhakar. 2002. Combining ability studies in Rabi Sorghum. Ann. agric. Res. New series, 23(3): 500-502.

Prabhakar, Elangovan, M. and Bahadure, D.M. 2013. Combining ability of new parental lines for flowering, maturity and grain yield in rabi sorghum. Electronic J. Plant Breeding, 4(3): 1241-1218.

Prakash, R., Ganeshmurty, K., Nirmalkumar, A. and Nagarajan, P. 2010. Combining ability for fodder yield and its components in sorghum (Sorghum bicolor (L.) Moench). Electronic $J$. Plant Breeding, 1(2):140-144.

Stephens, J.C. and Holland R.F. 1954. Cytoplasmic male sterility for hybrid sorghum seed production. Agron. J., 46: 20-23.

\section{How to cite this article:}

Ghorade, R.B., Vikas Mangal, Dipali P. Thakare, V.V. Kalpande and Pagire, K.S. 2017. Detection of Promising Cross Combinations on the Basis of Standard Heterosis and Specific Combining Ability in Kharif Sorghum. Int.J.Curr.Microbiol.App.Sci. 6(2): 356-361. doi: http://dx.doi.org/10.20546/ijcmas.2017.602.039 